\title{
ТКАНЕИНЖЕНЕРНЫЕ КОНСТРУКЦИИ ДЛЯ РЕГЕНЕРАТИВНОЙ МЕДИЦИНЫ НА ОСНОВЕ МЕЗЕНХИМАЛЬНЫХ КЛЕТОК ПУЛЬПЫ МОЛОЧНОГО ЗУБА И ПОЛИМЕРНЫХ МАТРИКСОВ НОВОГО ПОКОЛЕНИЯ
}

\author{
(С Вахрушев И.В. ${ }^{1}$, Антонов Е.Н. ${ }^{2}$, Суббот А.М. ${ }^{3}$, Новиков И.А. ${ }^{3}$, \\ Раева О.С. ${ }^{4}$, Ярыгин Н.В. ${ }^{5}$, Попов В.К. ${ }^{2}$, Ярыгин К.Н. ${ }^{4}$
}

\begin{abstract}
${ }^{1}$ Научный центр акушерства, гинекологии и перинатологии имени академика В.И. Кулакова, Москва; ${ }^{2}$ Институт фотонных технологий Федерального научно-исследовательского центра «Кристаллография и фотоника» РАН, Москва; ${ }^{3}$ Научно-исследовательский институт глазных болезней, Москва; ${ }^{4}$ НИИ биомедицинской химии имени В.Н. Ореховича, Москва; ${ }^{5}$ Московский государственный медико-стоматологический университет имени А.И. Евдокимова, Москва E-mail: vakhrunya@gmail.com
\end{abstract}

\begin{abstract}
Целью представленной работы являлась разработка подхода к созданию тканеинженерных конструкций с использованием культур мезенхимальных стромальных клеток и биодеградируемых синтетических полимерных матриксов нового поколения, полученных по технологии поверхностного селективного лазерного спекания. Первичные культуры мезенхимальных стромальных клеток были получены из пульпы молочных зубов, выпавших естественным путем. Клетки культивировали на матриксах в течение десяти дней после заселения. Оценку количества жизнеспособных клеток проводили при помощи набора CуtoTox Assay (Promega), основанного на колориметрическом измерении активности митохондриальных дегидрогеназ. Для визуализации клеток в составе тканеинженерных конструкций применяли сканирующую электронную микроскопию (СЭМ) с суправитальным лантаноидным контрастированием. В результате было показано, что разрабатываемые матриксы обеспечивают эффективную адгезию и пролиферацию клеток, и, следовательно, могут быть использованы в качестве клеточных носителей в тканевой инженерии.

Ключевые слова: поверхностно-селективное лазерное спекание, сканирующая электронная микроскопия, лантаноиды, мезенхимальные стволовые клетки, тканевая инженерия.
\end{abstract}

\section{TISSUE ENGINEERED CONSTRUCTS FOR REGENERATIVE MEDICINE BASED ON DECIDUOUS DENTAL PULP MESENCHYMAL CELLS AND NEW-GENERATION POLYMER MATRICES}

Vakhrushev I.V. ${ }^{1}$, Antonov E.N. ${ }^{2}$, Subbot A.M. ${ }^{3}$, Novikov I.A. ${ }^{3}$, Raeva O.S. ${ }^{4}$, Yarygin N.V. ${ }^{5}$, Popov V.K. ${ }^{2}$, Yarygin K.N. ${ }^{4}$

${ }^{1}$ V.I. Kulakov Research Center of Obstetrics, Gynecology, and Perinatology, Moscow; ${ }^{2}$ Insitute of Photonic

Technologies of Federal Reseach Center "Chrystallography and Photonics" RAS, Moscow; ${ }^{3}$ Research Institute of Eye

Diseases, Moscow; ${ }^{4}$ Institute of Biomedical Chemistry, Moscow; ${ }^{5}$ A.I. Evdokimov Moscow State University of Medicine and Dentistry, Moscow

The aim of the present work was to develop an approach for producing tissue engineered constructs based on mesenchymal stromal cell culture and new-generation biodegradable synthetic polymer matrices obtained by the technology of surfaceselective laser sintering. Primary mesenchymal stromal cells were derived from the pulp of naturally shed deciduous teeth. Following seeding, the cells were cultured on matrices for ten days. Cell viability was quantitatively assessed using CytoTox Assay (Promega) based on the colorimetric measurement of mitochondrial dehydrogenase activity. Cellular structure and spatial arrangement within a tissue-engineered matrix was visualized by scanning electron microscopy (SEM), using supravital lanthanoid staining. The results obtained showed that matrices under development enable good cell adhesion and proliferation, and hence can be used as a cell carrier in tissue engineering. Thus, the techniques of surface-selective laser sintering, which was developed by us, could find wide use in regenerative medicine.

Keywords: surface-selective laser sintering, scanning electron microscopy, lanthanoids, mesenchymal stromal cells, tissue engineering.

Технологии регенеративной медицины, активно развивающиеся в последнее время, открывают новые возможности для восстановления разнообразных повреждений организма. В общем виде они направлены на активацию регенеративного потенциала пациента и создания в области дефекта оптимальных условий для восстановления. Основным инструментом регенеративной медицины являются методы тканевой инженерии, как правило, подразумевающие имплантацию в зону повреждения мультипотентных клеток, иммобили- зованных на клеточном носителе, или матриксе, выполняющем функции трехмерного каркаса [12]. К матриксу предъявляется ряд критически важных требований, таких как возможность обеспечения адгезии достаточного количества клеток и их последующей пролиферации и дифференцировки, а также миграции прогениторных клеток со стороны организма реципиента. При этом матрикс должен быть нетоксичным и обладать адекватными механическими свойствами. Учитывая, что конечной целью терапевтического воздейст- 
вия является постепенное замещение имплантированной конструкции естественной тканью организма, материал матрикса должен обладать способностью к биодеградации. Среди синтетических материалов, применяемых для создания матриксов, хорошо себя зарекомендовали полимеры молочной и гликолевой кислот [7]. Материалы на их основе позволяют создавать трехмерные клеточные носители с заданной структурой и свойствами методами аддитивных технологий [6]. Что особенно важно, использование для производства матриксов сополимеров молочной и гликолевой кислот позволяет контролировать скорость резорбции материалов и подбирать ее таким образом, чтобы она соответствовала скорости регенерации ткани в области дефекта после имплантации [5].

В качестве клеточного материала для заселения матриксов при создании тканеинженерных конструкций чаще всего применяются культуры мезенхимальных стромальных клеток, получаемые из красного костного мозга или жировой ткани, а затем подвергаемые экспансии до получения необходимого количества в условиях in vitro. Однако возможности получения культур МСК из этих источников зачастую бывают ограничены, т.к. забор исходного материала для выделения клеток требует инвазивного вмешательства. Кроме того, в течение жизни клетки костного мозга и жировой ткани, подобно всем другим клеткам организма, стареют и подвергаются воздействию неблагоприятных факторам окружающей среды, что приводит к снижению их терапевтического потенциала [10]. Возможным решением данной проблемы является использование мультипотентных стромальных клеток из пульпы молочного зуба [9]. Их получение не связано с какими-либо рисками для донора, а также не обременено этическими ограничениями. Благодаря этому, пульпа молочного зуба является одним из наиболее перспективных источников прогениторных клеток для регенеративной медицины.

Целью настоящей работы являлась разработка процесса формирования биосовместимых полимерных матриксов на основе полилактогликолида (ПЛГ) методом поверхностно-селективного лазерного спекания (ПСЛС) и оценка их применимости для создания тканеинженерных конструкций в комплексе с МСК пульпы молочного зуба.

\section{МАТЕРИАЛЫ И МЕТОДЫ ИССЛЕДОВАНИЯ}

\section{Культуры клеток.}

Замороженные культуры МСК пульпы молочного зуба человека были взяты из криобанка Лаборатории клеточной биологии ИБМХ. После размораживания клетки культивировали в росто- вой среде (DMEM/F12 (1:1) с добавлением 10\% фетальной сыворотки крупного рогатого скота, 100 ед/мл пенициллина, 100 мкг/мл стрептомицина (все перечисленные реактивы - Gibco)) в $\mathrm{CO}_{2}$ инкубаторе в стандартных условиях $\left(37^{\circ} \mathrm{C}\right.$, $5 \% \mathrm{CO}_{2}, 80 \%$ влажности) до состояния 80-90\% конфлюэнтности, меняя среду два раза в неделю. Снятие клеток с поверхности пластика осуществляли путем инкубации в 0,25\% р-ре трипсина в смеси с раствором версена (1:1) при $37^{\circ} \mathrm{C}$ в течение 5 мин., после чего клетки осаждали центрифугированием и ресуспендировали в ростовой среде. Для проведения исследований были использованы клетки 4 пассажа.

\section{Изготовление матриксов.}

Экспериментальные образцы трехмерных матриксов на основе ПЛГ были изготовлены с использованием установки селективного лазерного спекания СЛС-100, разработанной в ИПЛИТ РАН. Для формирования матриксов использовался ПЛГ марки Purasorb PDLG 7507 (Purac Biochem bv, Нидерланды) с характеристической вязкостью 0,7 дл/г и с соотношением звеньев молочной и гликолевой кислот 75:25. Размер частиц порошка ПЛГ составлял порядка 50-100 мкм. В качестве сенсибилизатора поглощения лазерного излучения полимерным порошком в последний были добавлены наночастицы углерода (характеристическая площадь поверхности $\left.100 \mathrm{~m}^{2} / \Gamma\right)$ в количестве $0,1 \%$ по массе. Матриксы были изготовлены в виде дисков диаметром 12 мм и толщиной 1 мм. Перед заселением клетками их стерилизовали путем погружения в 70\% водный раствор этанола на 10-15 сек., а затем преинкубировали в ростовой среде в течение 24 ч.

Создание тканеинженерных конструкций.

Клетки переводили в суспензию, как это было описано выше, а затем наносили аликвоты клеточной суспензии в ростовой среде объемом 2 мл (концентрация клеток 200000 кл./мл) на матриксы, размещенные в 24-луночном культуральном планшете. Дальнейшее культивирование осуществляли в $\mathrm{CO}_{2}$ инкубаторе в стандартных условиях. Спустя 24 ч после нанесения клеток полученные образцы тканеинженерных конструкций переносили в чистые лунки планшета, заполненные ростовой средой.

Подготовка образцов и проведение СЭМисследования.

Образцы насыщались неодимом с использованием набора реактивов «BioREE» (OOO «Глаукон», Россия): образцы ополаскивали в изотоническом промывочном растворе (для исключения связывания с фосфатами контрастирующего вещества, после чего размещали в емкости с раствором контрастирующего вещества и экспонировали в течение 45 минут, затем препараты кратко- 
временно промывали для удаления излишков реагентов.

Подготовленные образцы размещали на предметном столике микроскопа (EVO LS10, CarlZeiss, Germany). Наблюдения велись в режиме низкого вакуума (ЕР, 70 Па), при ускоряющем напряжении 23 кВ и токе на образце 400-520 пА. Катод LaB6.

Оиенка количества жизнеспособных клеток.

Оценку количества жизнеспособных клеток в составе тканеинженерных конструкций осуществляли при помощи набора реагентов СуtoTox Assay (Promega) в соответствии с протоколом производителя, адаптированным к условиям конкретного эксперимента. Через 1 и 10 дней культивирования матриксы извлекали из ростовой среды, затем промывали три раза раствором $\mathrm{PBS}$, после чего помещали в чистые лунки, содержащие по 300 мкл PBS. Для лизирования клеточных мембран образцы подвергали трем циклам замораживания с последующим размораживанием. Далее аликвоты клеточного лизата объемом 10 мкл разводили деионизованной водой в соотношении 1:5, затем переносили их в 96-луночный планшет и смешивали с 50 мкл субстратного реагента, после чего инкубировали 60 мин. в темноте при комнатной температуре. По окончании инкубации реакцию останавливали путем внесения в лунки по 50 мкл стоп-реагента. Оптическую плотность измеряли при 490 нм на микропланшетном сканере Tecan Infinite MX300 (Tecan).

Статистическая обработка результатов.

Статистический анализ результатов проводили с помощью открытого программного пакета $\mathrm{R}$ (www.r-project.org). Для выявления различий между количествами жизнеспособных клеток использовали непараметрический критерий Уилкок-
сона-Манна-Уитни. Различие показателей признавали статистически значимым в том случае, если вычисленный уровень значимости (р) не превышал критического уровня 0,05 .

\section{РЕЗУЛЬТАТЫ ИССЛЕДОВАНИЯ И ИХ ОБСУЖДЕНИЕ}

В качестве клеточного материала для заселения матриксов нами были использованы первичные культуры МСК пульпы молочного зуба человека. Ранее нами было показано их соответствие основным критериям мультипотентных клеток мезенхимального ряда по рекомендациям Международного общества клеточной терапии (International Society of Cell Therapy, ISCT) [8], что подтверждало данные, полученные другими группами исследователей. В частности была показана экспрессия типичного для МСК профиля поверхностных CD-маркеров [2], а также способность клеток к дифференцировке в различных направлениях $[11,1]$. В настоящей работе были использованы культуры МСК пульпы молочного зуба 4-го пассажа, полученные ранее от здорового донора на условиях добровольного информированного согласия и подвергнутые криоконсервации. Культуры клеток представляли собой популяцию распластанных клеток с характерной фибробластоподобной морфологией (рис. 1). Для получения тканеинженерных конструкций клетки наносили в виде суспензии на поверхность матриксов. Спустя 1 и 10 дней после заселения образцы извлекали и проводили оценку количества жизнеспособных клеток в их составе путем как непосредственного наблюдения с помощью СЭМ, так и путем колориметрического измерения лактатдегидрогеназной активности.

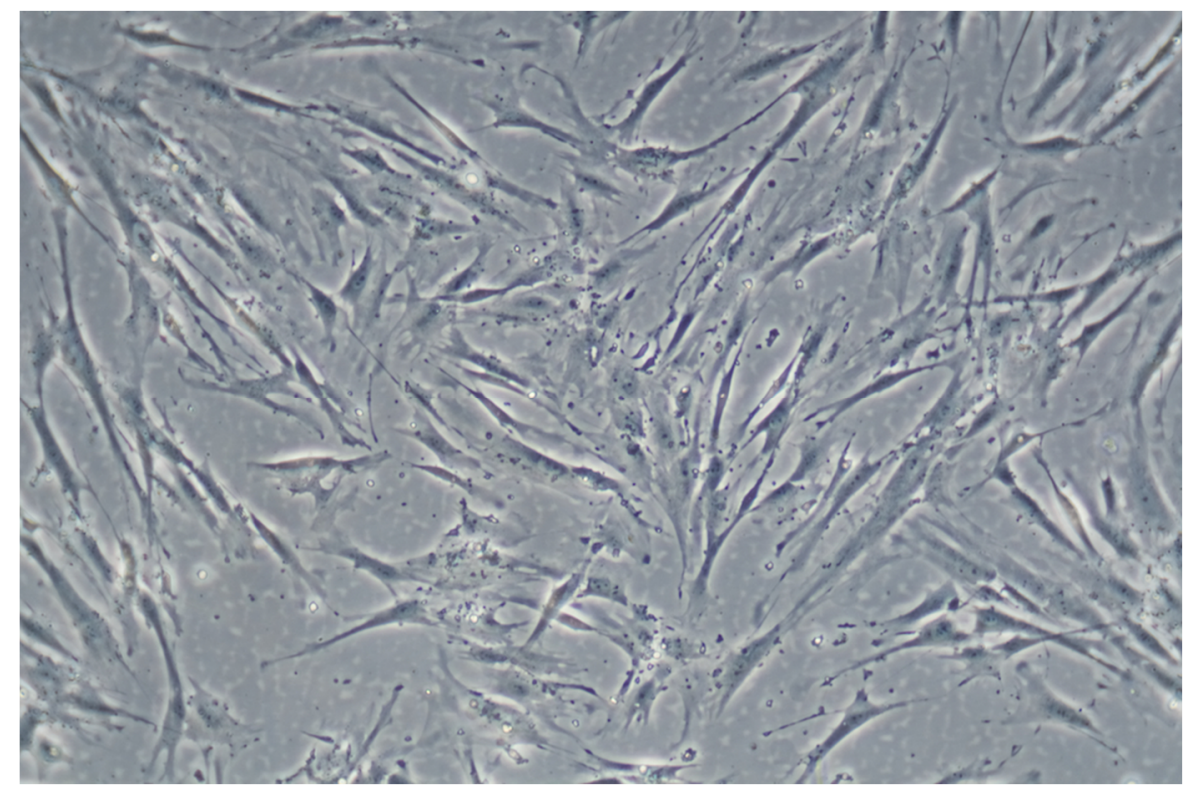

Рис. 1. Первичные культуры МСК пульпы молочного зуба. Фазово-контрастная микроскопия. Увеличение $\times 100$. 


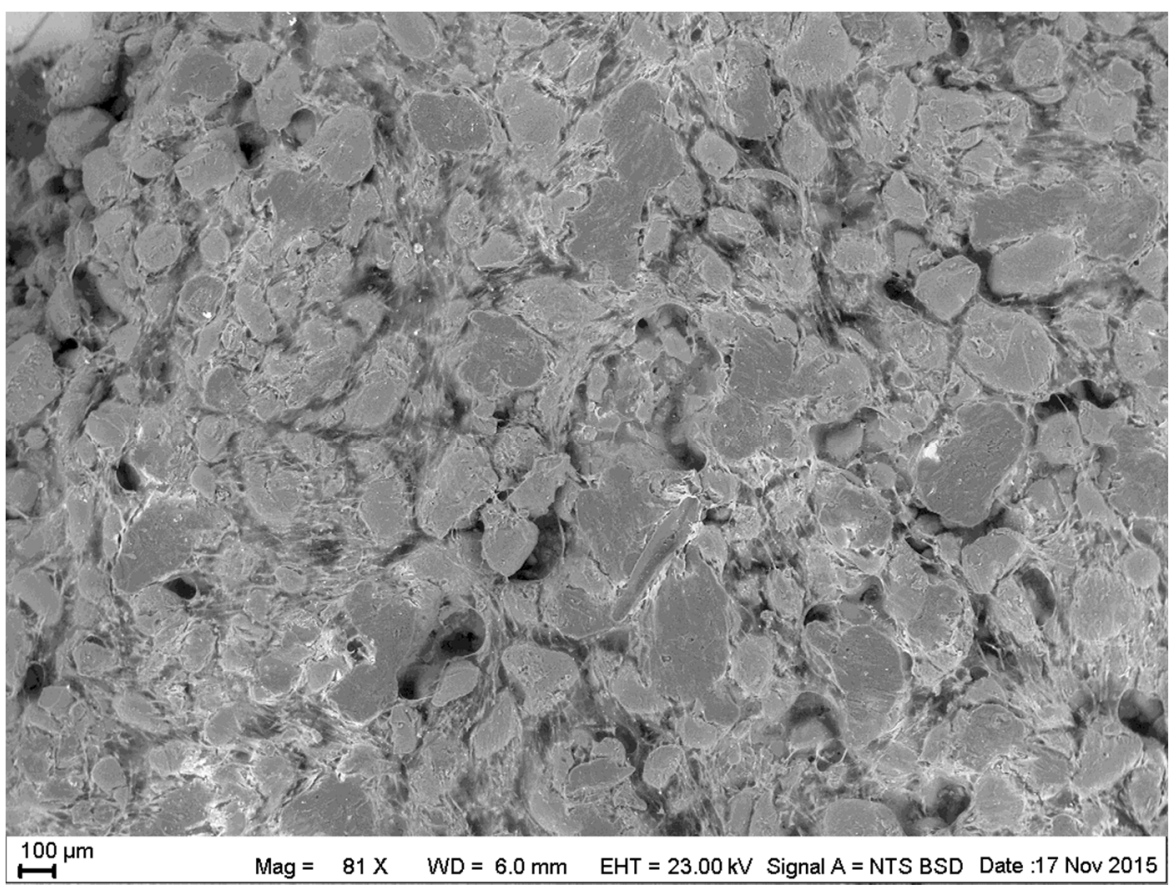

A.

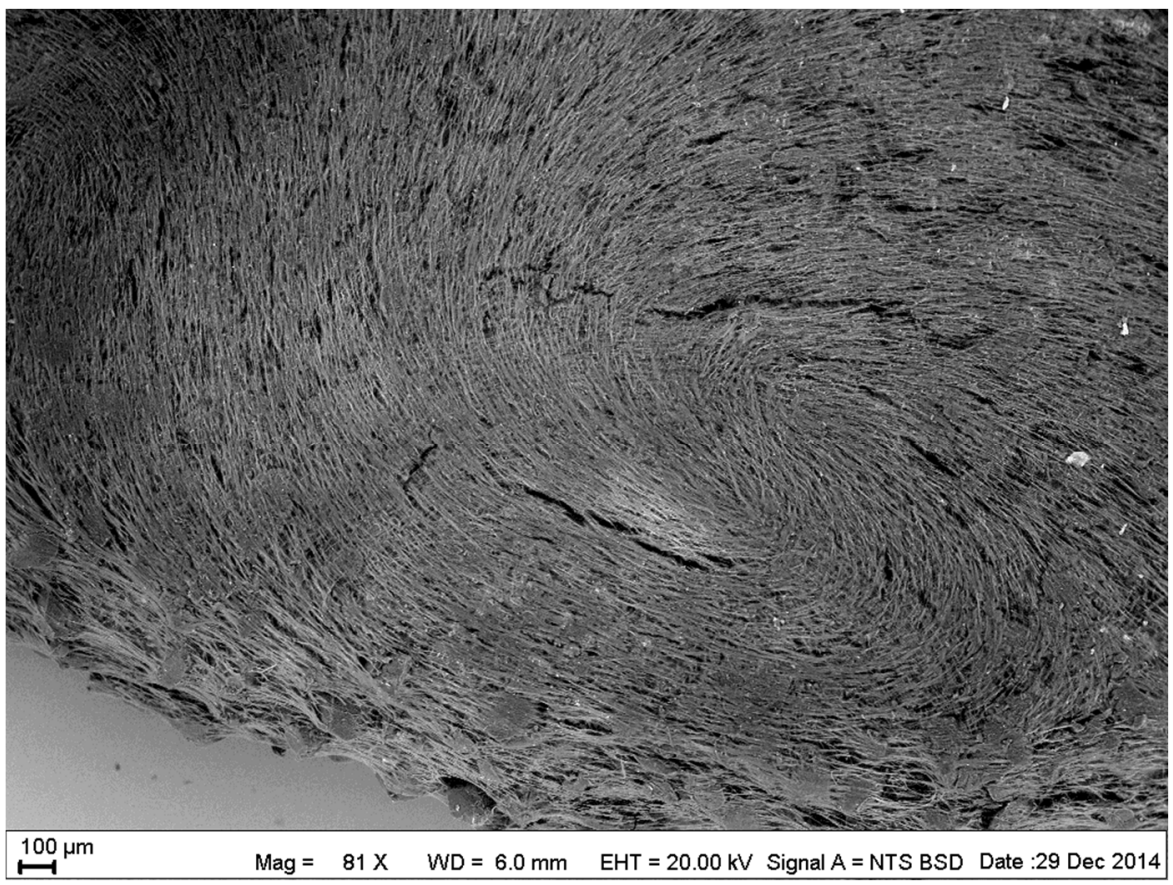

Б.

Рис. 2. МСК пульпы зуба, культивируемые на матриксе на основе полилактогликолида. А - 1 сут. после заселения, Б - 10 сут. после заселения. СЭМ с лантаноидным контрастированием.

Для визуализации клеток нами был применен новый метод СЭМ с суправитальным лантаноидным контрастированием [4]. Суправитальное окрашивание клеточных культур препаратом на основе хлорида неодима позволяет сохранить нормальную морфологию клеток и предоставило возможность оценить морфологию клеток и особенности их взаимодействия с материалом матрикса [3].

Через 1 день после нанесения клеточной суспензии на поверхности образцов наблюдались скопления многочисленных прикрепившихся клеток (рис. 2, а), что свидетельствовало об отсутствии цитотоксичности со стороны материала, а также о том, что структура его поверхности обеспечивала эффективную клеточную адгезию. Результаты исследования, проведенного на 10-й день, показали, что матриксы также способствуют пролиферативной активности МСК пульпы зуба. В результате активного деления поверхность образцов оказалась покрыта плотным слоем клеток (рис. 2, б). Наблюдались многочисленные 


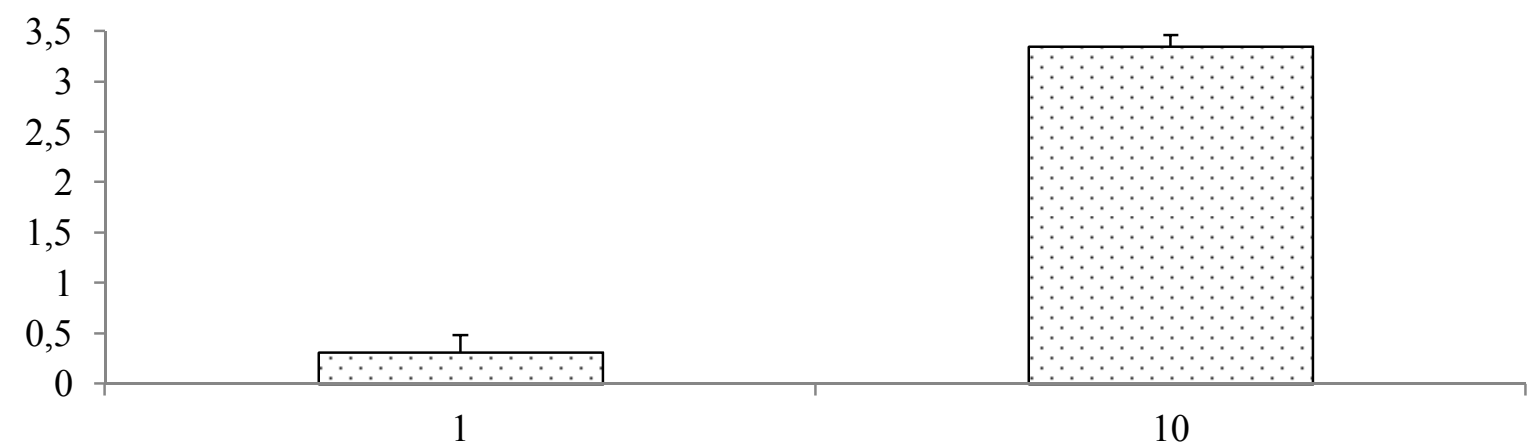

Рис. 3. Пролиферация МСК пульпы молочного зуба в составе тканеинженерных конструкций. По оси абсцисс - оптическая плотность, отражающая кол-во жизнеспособных клеток; по оси ординат - время культивирования (дни). Доверительные интервалы отображают стандартную ошибку.

клеточные контакты, а также накопление межклеточного вещества.

Биохимическое измерение количества жизнеспособных клеток в образцах тканеинженерных конструкций, проведенное с помощью набора реагентов CytoTox 96 (Promega), подтвердило выводы, сделанные на основе визуального наблюдения. Согласно полученным данным (рис. 3), уровень лактатдегидрогеназной активности, прямо пропорциональный числу клеток, увеличился за 10 дней культивирования более чем в 10 раз.

Таким образом, результаты настоящей работы позволяют сделать вывод о том, что разработанный нами процесс формирования полилактогликолидных структур методом ПСЛС пригоден для производства носителей клеточного материала в тканевой инженерии. Удачное сочетание состава материала и структуры его поверхности эффективно обеспечивает клеточную адгезию и пролиферацию. Следует также отметить, что в состав матриксов могут быть дополнительно введены лекарственные препараты, факторы роста и индукторы дифференцировки клеток [3]. Все вышесказанное дает возможность заключить, что представленный нами подход к созданию тканеинженерных конструкций может оказаться весьма эффективным и найти свое практическое применение в регенеративной медицине.

Работа поддержана Российским фондом фундаментальных исследований (грант № 16-2907322 ОФИ_М) (в части проведения микроскопических и биохимических исследований), а также Российским научным фондом (грант № 14-2500179) (в части получения и ведения культур клеток).

\section{ЛИТЕРАТУРА}

1. Вахрушев И.В., Смирнов В.В., Гольдберг М.А., Каралкин П.А., Лупатов А.Ю., Баринов С.М., Ярыгин К.H. Влияние различных кальцийфосфатных материалов на мультипотентные мезенхимальные клетки пульпы молочного зуба (SHED-клетки) in vitro // Клеточные технологии в биологии и медицине. - 2013. - № 1. - С. 25-27.

2. Вахрушев И.В., Суздальцева Ю.Г., Бурунова В.В., Каралкин П.А., Лупатов А.Ю., Ярыгин К.Н. Мезенхимальные клетки пульпы молочного зуба: цитофенотип и первичная оценка возможности применения в тканевой инженерии костной ткани // Клеточные технологии в биологии и медицине. 2010. № 1. - С. 55-60.

3. Новиков И.А., Вахрушев И.В., Антонов Е.Н., Ярыгин К.Н., Суббот А.М. Визуализация мезенхимных стромальных клеток в двумерных и трехмерных культурах методом сканирующей электронной микроскопии с лантаноидным контрастированием// Клеточные технологии в биологии и медицине. - 2016. - № 4. - С. 248-254.

4. Новиков И.А., Суббот А.М., Федоров А.А., Грибоедова И.Г. Суправитальное контрастирование лантаноидами для визуализации структуры биологических образцов на сканирующем электронном микроскопе // Гены \& Клетки. - 2015. T. 10, № 2. - C. 90-96.

5. Antonov E.N., Bagratashvili V.N., Howdle S.M., Konovalov A.N., Popov V.K., Panchenko V.Y. Fabrication of polymer scaffolds for tissue engineering using surface selective laser sintering // Laser Physics. - 2006. - Vol. 16, N 5. - C. 774-787.

6. Antonov E.N., Bagratashvili V.N., Whitaker M.J., Barry J.J., Shakesheff K.M., Konovalov A.N., Popov V.K., Howdle S.M. Three-Dimensional Bioactive and Biodegradable Scaffolds Fabricated by SurfaceSelective Laser Sintering // Adv Mater. - 2004. Vol. 17, N 3. - C. 327-330.

7. Asti A., Gioglio L. Natural and synthetic biodegradable polymers: different scaffolds for cell expansion and tissue formation // Int J Artif Organs. 2014. - Vol. 37, N 3. - C. 187-205.

8. Dominici M., Le Blanc K., Mueller I., SlaperCortenbach I., Marini F., Krause D., Deans R., Keating A., Prockop D., Horwitz E. Minimal criteria for defining multipotent mesenchymal stromal cells. The International Society for Cellular Therapy position statement // Cytotherapy. - 2006. - Vol. 8, N 4. - C. 315-317.

9. Huang G.T., Gronthos S., Shi S. Mesenchymal stem cells derived from dental tissues vs. those from other sources: their biology and role in regenerative 
medicine // J Dent Res. - 2009. - Vol. 88, N 9. C. 792-806.

10. Liu H., Xia X., Li B. Mesenchymal stem cell aging: Mechanisms and influences on skeletal and nonskeletal tissues // Exp Biol Med (Maywood). 2015. - Vol. 240, N 8. - C. 1099-1106.

11. Nuti N., Corallo C., Chan B.M., Ferrari M., GeramiNaini B. Multipotent Differentiation of Human Dental
Pulp Stem Cells: a Literature Review // Stem Cell Rev. - 2016. - Vol. 12, N 5. - C. 511-523.

12. Sailaja G.S., Ramesh P., Vellappally S., Anil S., Varma H.K. Biomimetic approaches with smart interfaces for bone regeneration // J Biomed Sci. 2016. - Vol. 23, N 1. - C. 77. 